\title{
PHYLOGENETIC ANALYSIS FOR DETECTION OF MULTIPLE FOULING EVENTS: A PILOT STUDY OF BARNACLES AT MOOREA ISLAND (FRENCH POLYNESIA)
}

\author{
BY \\ ALBA ARDURA ${ }^{1,3,4}$ ), SERGE PLANES ${ }^{2,3}$ ) and EVA GARCIA-VAZQUEZ ${ }^{1}$ ) \\ $\left.{ }^{1}\right)$ Department of Functional Biology, University of Oviedo, \\ C/Julian Claveria s/n., 33006 Oviedo, Spain \\ ${ }^{2}$ ) USR 3278, CNRS-EPHE, Centre de Recherche Insulaire et Observatoire de l'Environnement \\ (CRIOBE), BP 1013-98 729, Papetoai, Moorea, French Polynesia \\ ${ }^{3}$ ) Laboratoire d'Excellence "Corail”, 58 avenue Paul Alduy, 66860 Perpignan, France
}

\begin{abstract}
Sequencing the cytochrome oxidase I gene and 16rRNA gene as DNA Barcodes as a phylogenetic methodology, we identified the origin of two invasive barnacles sampled from Vai' are Bay (Moorea Island) in 2011: Chthamalus proteus and Amphibalanus amphitrite. Reconstructed phylogenies strongly support multiple introductions of Chthamalus proteus: from a Brazilian lineage first identified at the island in 2004 and from a lineage located in Hawaii that same year. The unique Amphibalanus amphitrite haplotype clustered with lineages distributed from Japan to Malaysia. The results demonstrate multiple introduction events from different origins, that may enhance invasion processes in South Pacific islands.
\end{abstract}

Key words. - Barnacles, Moorea, phylogenetic analysis, biofouling, COI, 16S

\section{RÉSUMÉ}

En utilisant le séquençage du gène de la cytochrome oxydase I et du gène de l'ARNr 16 par la méthode des code-barres d'ADN, nous avons déterminé l'origine phylogénétique de deux balanes invasives récoltées dans la Baie de Vai'are (île de Moorea) en 2011 : Chthamalus proteus et Amphibalanus amphitrite. La reconstruction phylogénétique soutien fortement les introductions multiples de Chthamalus proteus : d'une première lignée brésilienne identifiée dans l'île en 2004, et d'un lignée localisée à Hawaï la même année. L'unique haplotype Amphibalanus amphitrite se regroupe avec des lignées distribuées du Japon à la Malaisie. Les résultats démontrent des introductions multiples de différentes origines, qui pourraient favoriser les processus d'invasion dans les îles du Pacifique sud.

${ }^{4}$ ) Corresponding author; e-mail: alarguti@ hotmail.com

(C) Koninklijke Brill NV, Leiden, 2016 


\section{INTRODUCTION}

There are different gateways for introduction of exotic species into a habitat. Shipping is believed to be one of the most important pathways for transfer of non-indigenous species across marine regions (Leppakoski et al., 2002). This pathway involves several potential vectors-transport of organisms in ballast water and ballast tank sediments, and fouling of hull, sea chests, anchors and anchor chains, etc. (Hewitt et al., 2009), depending on adult or larval biology status of the species (Farrapeira et al., 2007; Yamaguchi et al., 2009; Tøttrup et al., 2010). Ballast water (BW) is recognized as the most significant of these vectors (Molnar et al., 2008). Approximately 2.2 to 12 billion tonnes of BW are transported across the world oceans annually (Endresen et al., 2004), transferring some 7000 species daily in the process (Gollasch \& David, 2011).

Maritime transport is not only a source of invaders but also a paradigmatic vector of long-distance dispersal with relatively predictable patterns if the main routes are known (e.g., Wonham et al., 2001; Occhipinti-Ambrogi \& Galil, 2010). The spread can be predicted when the vectors are known and also when the natural population structure in native locations, an indicator of the natural dispersal capacity, is known (Gaither et al., 2013). The widespread use of maritime highways for commercial and recreational interchanges provides opportunities for repeated waves of invasions (Galil et al., 2007). Multiple invasion hits can be traced employing phylogenetic methodology when geographically separated lineages can be identified from DNA sequences. An example is the barnacle Chthamalus proteus Dando \& Southward, 1980, native to tropical Atlantic waters. The origin of its invasion in the Pacific Ocean has been demonstrated to be diverse because lineages from Brazil, Panama and Caribbean have been unambiguously identified in different Pacific regions using the Barcoding cytochrome oxidase gene COI (Zardus \& Hadfield, 2005).

In other cases, the fouling behaviour of the species can increase the gene flow among distant populations and, thus, homogenize genetic structuring making the origin determination of the invasion difficult. An example is the barnacle Amphibalanus amphitrite (Darwin, 1854), which is distributed in warm and temperate waters worldwide, suggesting that it is dispersed through humanmediated activities via ballast water for larvae and via vessels fouling for adults in long distances routes (Chen et al., 2014). It is believed that the expansion of global trade in the $20^{\text {th }}$ century has led to transport of A. amphitrite from IndoPacific waters to those of Europe and even to North and South America (Carlton et al., 2011).

In the present study we developed a phylogenetic approach for determining the most likely origin of two fouling barnacles (C. proteus and A. amphitrite) settled 
in the main port of the Moorea Island: Vaiare (French Polynesia). This island is part of a biodiversity hotspot (Roberts et al., 2002) and barnacle invasions can seriously compromise the integrity of coral reef ecosystem (e.g., Coles \& Eldredge, 2002). Chthamalus proteus of Brazilian origin was detected there in 2004 (Zardus \& Hadfield, 2005). In the present study the origin of barnacles sampled in 2011 was traced employing the same methodology to test the possibility of multiple invasion hits, from the same or different origins, occurring in the same places.

\section{MATERIAL AND METHODS}

\section{Sampling}

Samples were taken from 16 points located in different ecosystems within the coral reefs that surround the Moorea Island (Richard, 1985): from water channels in Papetoai, Maharepa and Temae; from deep lagoons in Vaiare, Farehau and Afareaitu; from fringing reefs in Tiahura, Maatea, Atiha, Vaianae, Haapiti, Tiki and Hauru; and finally from bay environments in Opunohu, Paopao and EntreDeux-Baies (Ardura et al., 2015). Exotic barnacles were only detected in Vaiare port area.

Exotic barnacles (the Caribbean barnacle Chthamalus proteus and the striped acorn barnacle Amphibalanus amphitrite) were visually identified and manually sampled ( $N=20$ of each species) randomly from approximately $200 \mathrm{~m}^{2}$ in the intertidal habitat of the rocky shore close to the marina of Vaiare, approximately at $500 \mathrm{~m}$ from the Moorea Ferry Terminal, in August 2011. The exact coordinates of the sampling point are $17.304^{\circ} \mathrm{S} 149.549^{\circ} \mathrm{W}$.

\section{Genetic analysis}

Total DNA was extracted from the samples using the E.Z.N.A. Mollusc DNA kit (IOMEGA, bio-tek), following manufacturer's instructions. The tubes were stored at $4{ }^{\circ} \mathrm{C}$ for immediate DNA analysis, and aliquots were frozen at $-20^{\circ} \mathrm{C}$ for longtime preservation.

A fragment of the partial COI gene was amplified by polymerase chain reaction (PCR), employing the primers described by Geller et al. (2013). The amplification reaction was performed in a total volume of $40 \mu \mathrm{l}$, consisting of $1 \times$ Promega (Madison, WI) buffer, $2.5 \mathrm{mM} \mathrm{MgCl}_{2}, 0.25 \mathrm{mMdNTPs}, 20$ pmol of each primer, approximately $20 \mathrm{ng}$ of template DNA and $1 \mathrm{U}$ of DNA Taq polymerase (Promega), and the following PCR conditions: initial denaturing at $95^{\circ} \mathrm{C}$ for 5 minutes, 35 cycles of denaturing at $95^{\circ} \mathrm{C}$ for 1 minute, annealing at $48^{\circ} \mathrm{C}$ for 1 minute, extension at $72^{\circ} \mathrm{C}$ for 1 minute and final extension at $72^{\circ} \mathrm{C}$ for 5 minutes. 
Additional sequencing of the mitochondrial 16S rRNA gene with the primers described by Palumbi (1996) was carried out for both species in order to confirm the taxonomic identification with a second marker. The amplification reaction was performed in a total volume of $40 \mu \mathrm{l}$ with the same conditions described above for the COI gene and the following PCR conditions: initial denaturing at $95^{\circ} \mathrm{C}$ for 5 minutes, 30 cycles of denaturing at $94^{\circ} \mathrm{C}$ for 1 minute, annealing at $55^{\circ} \mathrm{C}$ for 1 minute, extension at $72^{\circ} \mathrm{C}$ for 2 minutes and final extension at $72^{\circ} \mathrm{C}$ for 7 minutes.

PCR products were visualised in $2 \%$ agarose gels with $3 \mu \mathrm{lof} 10 \mathrm{mg} / \mathrm{ml}$ ethidium bromide. Sequencing was performed at Macrogen Europe (The Netherlands).

\section{Sequence edition and phylogenetic analysis}

Sequences were visualized and edited employing the BioEdit Sequence Alignment Editor software (Hall, 1999) and they were aligned with the ClustalW application (Thompson et al., 1994) included in BioEdit. The sequences obtained were compared with international databases employing the program BLAST within NCBI (http://www.ncbi.nlm.nih.gov/) and BOLD system (http://www. boldsystems.org/) for identifying the species.

Sequences obtained in this work were used together with GenBank A. Amphitrite (KC138445, KM211362-KM211497) and C. proteus (AY822889, AY822950, AY822955, AY822956, AY822959, AY822961, AY822963, AY822964, AY822975, AY822984, AY822998, AY823005, AY823008 and AY823026) sequences from Chen et al. (2014) and Zardus \& Hadfield (2005), respectively, for subsequent phylogenetic analysis.

The phylogenetic analysis was performed with the software MEGA 6.0 (Tamura et al., 2013). Phylogenetic trees containing the reference and presently sequenced $\mathrm{COI}$ fragments were reconstructed using this software and selecting the Maximum Likelihood (ML) algorithm. The molecular substitution model was chosen using the software jModeltest (Posada, 2008), using a corrected Akaike information criterion (AICc), to determine the best suited model of sequence evolution and accompanying evolutionary parameter values for the data. Robustness of the ML topology in this case was assessed using 1000 bootstrap replicates.

Genetic differentiation between populations was measured with FSTs statistics, which is based on differences in nucleotide diversity between haplotypes. The software Arlequin (Excoffier et al., 2005) was employed for estimates of FSTs values and their statistical significance between samples pairs, i.e., the significance of population differentiation, with 10000 permutations for significance.

A median-joining network (Bandelt et al., 1999) was constructed to represent visually the intra-specific genealogy of the dataset of haplotypes and their relative frequencies in the sampled populations using the software network 5.0 (avail- 
able online at http://www.fluxus-technology.com), with default settings. The haplotypes table was made with the same software.

\section{RESULTS}

The 20 COI sequences obtained from Moorea Island barnacle samples (10 per species), 615 nucleotides long, were unambiguously assigned in both BOLD and GenBank to two species: Chthamalus proteus and Amphibalanus amphitrite. The results were confirmed with $16 \mathrm{~S}$ rRNA genes, with the same number of sequences (20, 10 per species), 485 nucleotides long, that also gave the closest match with these species in the GenBank database (Accession numbers KJ663820 and KJ663821 for the 16S rDNA haplotypes found for the $C$. proteus and A. amphitrite samples in this study, respectively).

The COI sequences of Chthamalus proteus corresponded to two different haplotypes, each of them found in 50\% of the cases. They were submitted to GenBank under accession numbers KJ663817 and KJ663818. The dataset containing these two haplotypes and the reference sequences with $>97 \%$ identity (table I) best fitted the mutation model of Tamura \& Nei (1993), with a proportion of invariant sites $(\operatorname{TrN}+\mathrm{I})$; which was employed in the settings for reconstructing the ML phylogenetic tree. In the phylogenetic tree obtained from these sequences (fig. 1a), both haplotypes clustered with the Brazilian and Hawaiian lineage with a small bootstrap, which could suggest a secondary introduction from Hawaii in some cases. The haplotype network obtained (fig. 1b) supports this suggestion, since both haplotypes (H14 and H15) clustered with Brazilian and Hawaiian ones (H1, H2 and H5) but not in strong way.

The COI sequences matching with Amphibalanus corresponded to one unique haplotype which was submitted to GenBank under Accession number KJ663819. The ML phylogenetic tree (fig. 2) was constructed using the mutation model of Tamura \& Nei (1993), with a proportion of invariant sites $(\operatorname{TrN}+\mathrm{I})$ and includes 16 other Amphibalanus sequences, representing each clade described by Chen et al. (2014) from GenBank (table I), confirming the species assignment of A. amphitrite obtained from BLAST. From the ML phylogenetic tree the origin area of the individuals found in Moorea Island was closer to clade 1 described by Chen et al. (2014), because our haplotype clustered together with this clade and separated from the branch that contained the other two clades. Besides, the genetic distances calculated (FSTs), together with the haplotype network analysed, clarify the closest population of Moorea Island in the same direction (table II, fig. 3). These genetic distances were calculated based on the nucleotides composition of each sequence; in table III we can see the differences inside clade 1 with the representative haplotypes described by Chen et al. (2014) together with Moorea haplotype found in this study. 


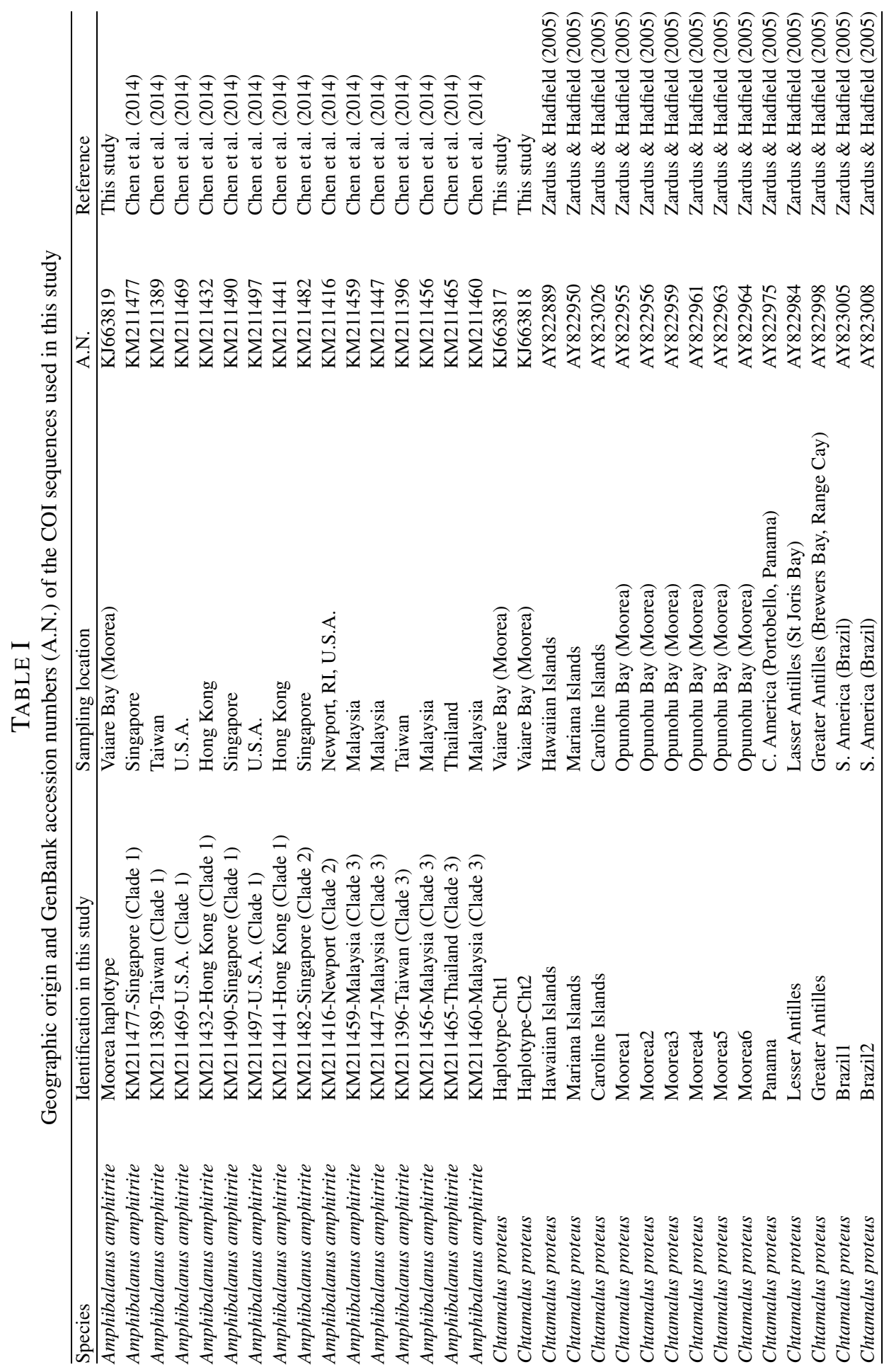




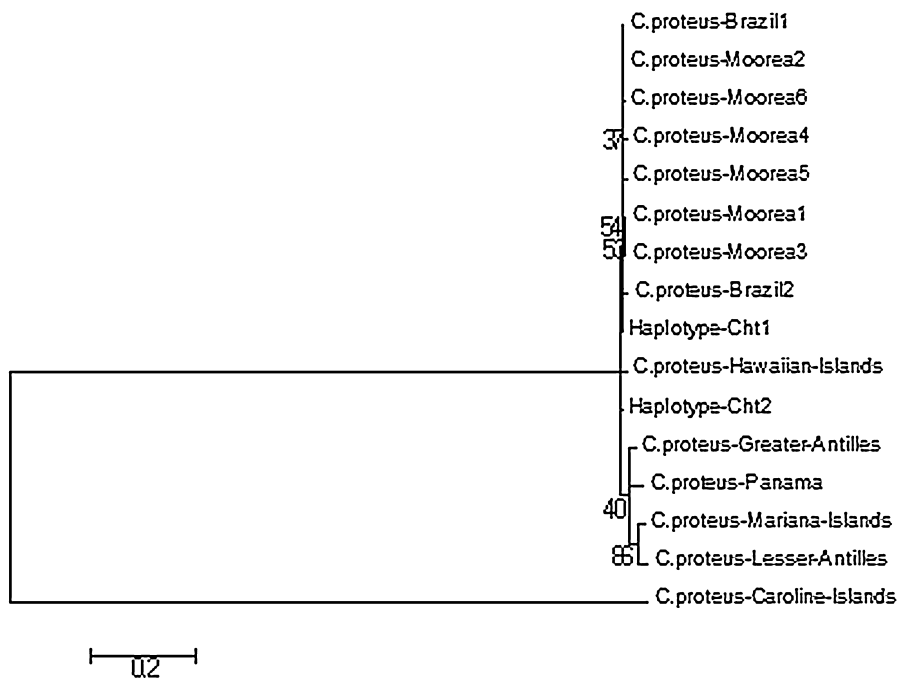

(a)

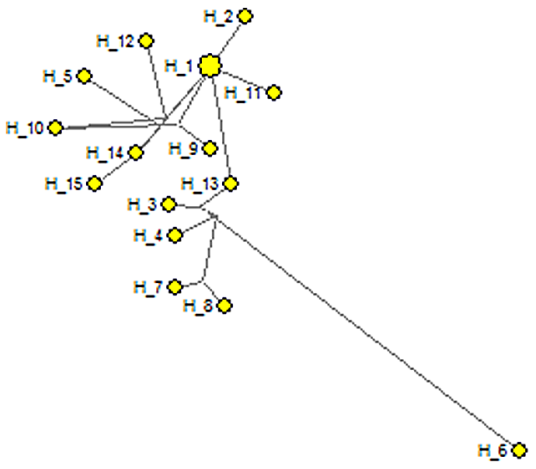

$\begin{array}{ll}\text { H1: Brazil-1, Moorea-2 } & \text { H9: Moorea-1 } \\ \text { H2: Brazil-2 } & \text { H10: Moorea-3 } \\ \text { H3: Parama } & \text { H11: Moorea-4 } \\ \text { H4: Greater-Antilles } & \text { H12: Moorea-5 } \\ \text { H5: Hawailar-Islands } & \text { H13: Moorea-6 } \\ \text { H6: Caroline-Islands } & \text { H14: Cht-1 } \\ \text { H7: Mariana-Islands } & \text { H15: Cht-2 } \\ \text { H8: Lesser-Antilles } & \end{array}$

(b)

Fig. 1. (a) Maximum Likelihood phylogenetic tree constructed based on COI gene fragment containing the two haplotypes found in this study from Moorea and other Chtamalus proteus sequences from the GenBank. Bootstrap values presented in percent. (b) Median-joining network showing the relationships among the same sequences described in the ML phylogenetic tree defined by COI sequence variation. This figure is published in colour in the online version of this journal, which can be accessed via http://booksandjournals.brillonline.com/content/journals/15685403.

\section{DISCUSSION}

Our results indicate multiple fouling hits introducing invasive barnacle species to small islands such as Moorea. Chthamalus proteus was described in another bay of the island for the first time in 2004. Seven years later it has been localised in a different bay, and in addition we identified two haplotypes; one from Brazil (GB-AN AY823005 and AY823008) (as the previously described lineage introduced in Moorea) and another one, probably from Hawaii (GB-AN 


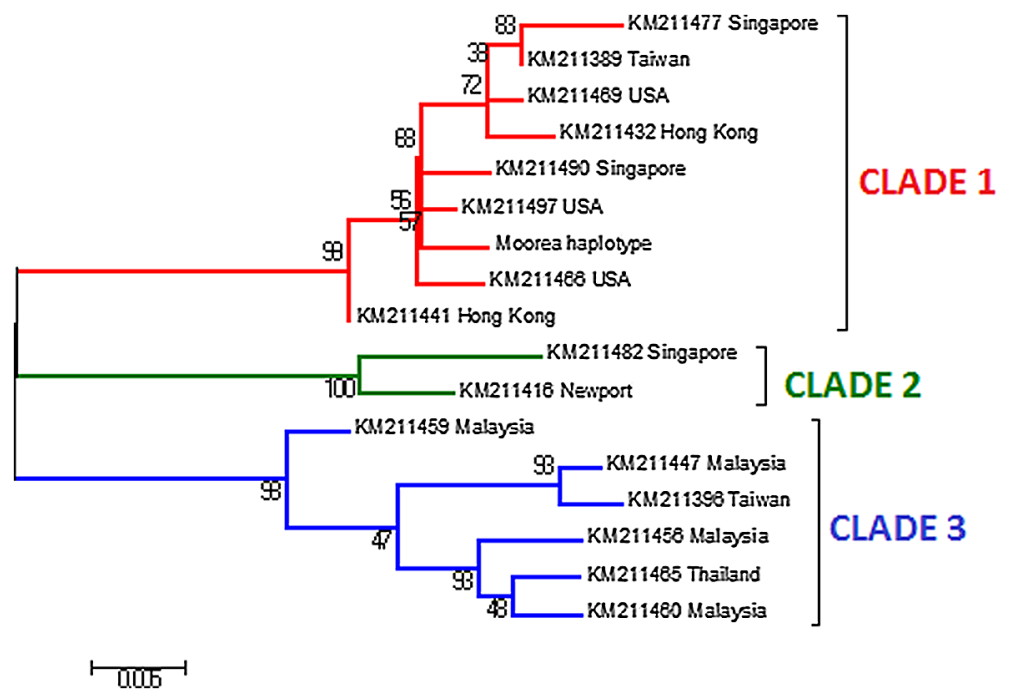

Fig. 2. Maximum Likelihood phylogenetic tree constructed based on COI gene fragment containing the haplotype found in this study from Moorea and other Amphibalanus sequences from the GenBank. Bootstrap values presented in percent. This figure is published in colour in the online edition of this journal, which can be accessed via http://booksandjournals.brillonline.com/content/ journals/15685403.

KM211389, KM211432, KM211441, KM211477 and KM211490), not previously described. This second one is likely to originate from a later introduction from Hawaii, most likely via maritime transport since it was sampled near the main marina of Moorea. The main way of expansion of $C$. proteus is likely to be secondary transfers by fouling rather than natural dispersion. This is inferred from a lot of shorter continuous extents of spread or CES (geographical distance over which there is suitable habitat and no gaps in distribution of greater than $100 \mathrm{~km}$ ), which is more probable than maximum extent of spread in its introduced range in Hawaii (Gaither et al., 2013). However the CES reported for this species in Hawaii was $529 \mathrm{~km}$, which exceeds by far the distance between Opunohu Bay (where

TABLE II

Test for significance differentation between populations based on pairwise genetic distances (FSTs) with COI sequences for $A$. amphitrite

\begin{tabular}{lcccc}
\hline & Clade 1 & Clade 2 & Clade 3 & Moorea Island \\
\hline Clade 1 & - & & & \\
Clade 2 & $0.80784^{*}$ & - & & \\
Clade 3 & $0.80067^{*}$ & $0.70884^{*}$ & - & \\
Moorea Island & $0.40409^{*}$ & $0.98245^{*}$ & $0.83931^{*}$ & - \\
\hline
\end{tabular}

$* p<0.05$. 


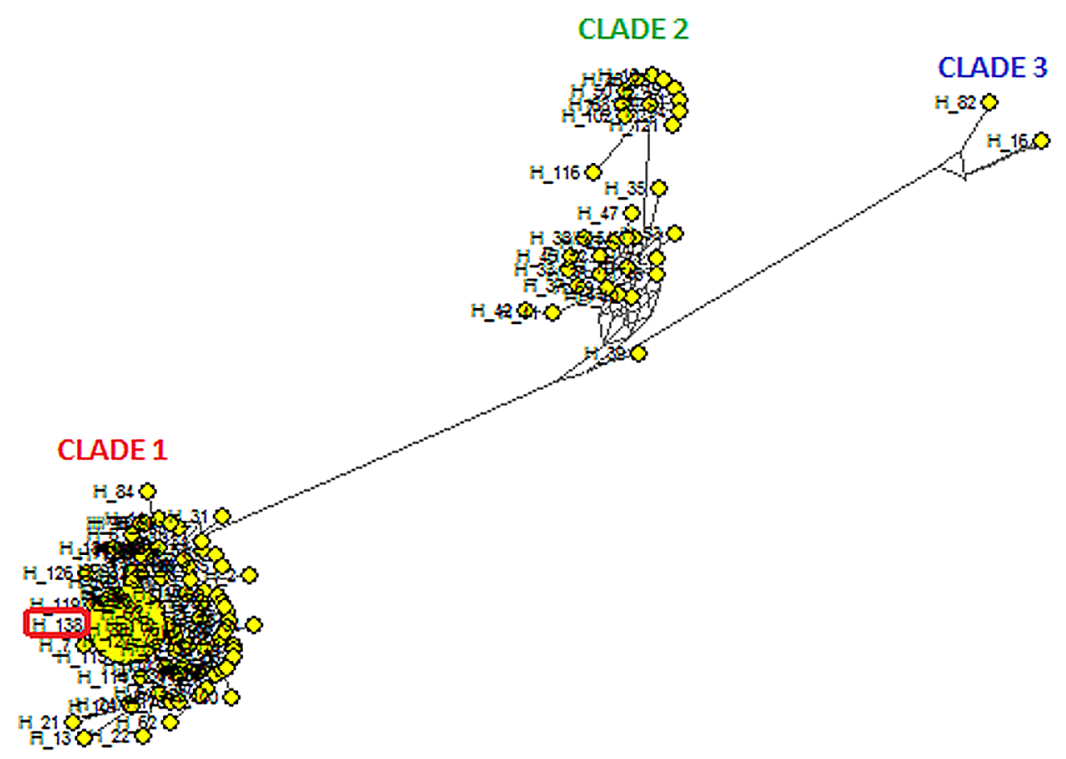

Fig. 3. Median-joining network showing the relationships among the Moorea Amphibalanus haplotype (H-138) and the 3 clades described by Chen et al. (2014), defined by COI sequence variation. This figure is published in colour in the online edition of this journal, which can be accessed via http://booksandjournals.brillonline.com/content/journals/15685403.

the species was reported in 2004 , coordinates $17.504^{\circ} \mathrm{S} 149.856^{\circ} \mathrm{W}$ ) and Vaiare, roughly $25 \mathrm{~km}$ of coastline. The possibility of natural dispersion from Opunohu Bay cannot be ruled out; moreover, the close proximity of our Haplotype 1 with that described from Moorea Island in 2004 seems to support the hypothesis of a natural expansion along the Moorea's coastline.

For Amphibalanus amphitrite the closer reference sequence was obtained from acorn barnacles from the region from Japan to Malaysia, correspond to the clade 1 described by Chen et al. (2014) (figs. 2 and 3). Additional populations are found in Australia, India and Saudí Arabia, but whether A. amphitrite is native or introduced to these regions is yet unknown (Chen et al., 2014). Besides, this clade is also found in Hawaii, California and North Carolina, all regions where it has long been recognised as a non-native species (Carlton \& Eldredge, 2009; Carlton et al., 2011). Despite of the ambiguity about the native-non-native distribution of the species, its transport on fouled ships' hulls and possibly, more recently, as larvae in ballast water has doubtlessly contributed to the global distribution of different clades (figs. 2 and 3). Therefore, the way of introduction to Moorea Island was likely maritime (e.g., Mineur et al., 2012), as in the case of Chthamalus. However, the previous presence of this species in Moorea Island cannot be discarded, and the conditions for primary or secondary transfer cannot be deduced from the present data. Amphibalanus amphitrite has been described in so many places that it could 


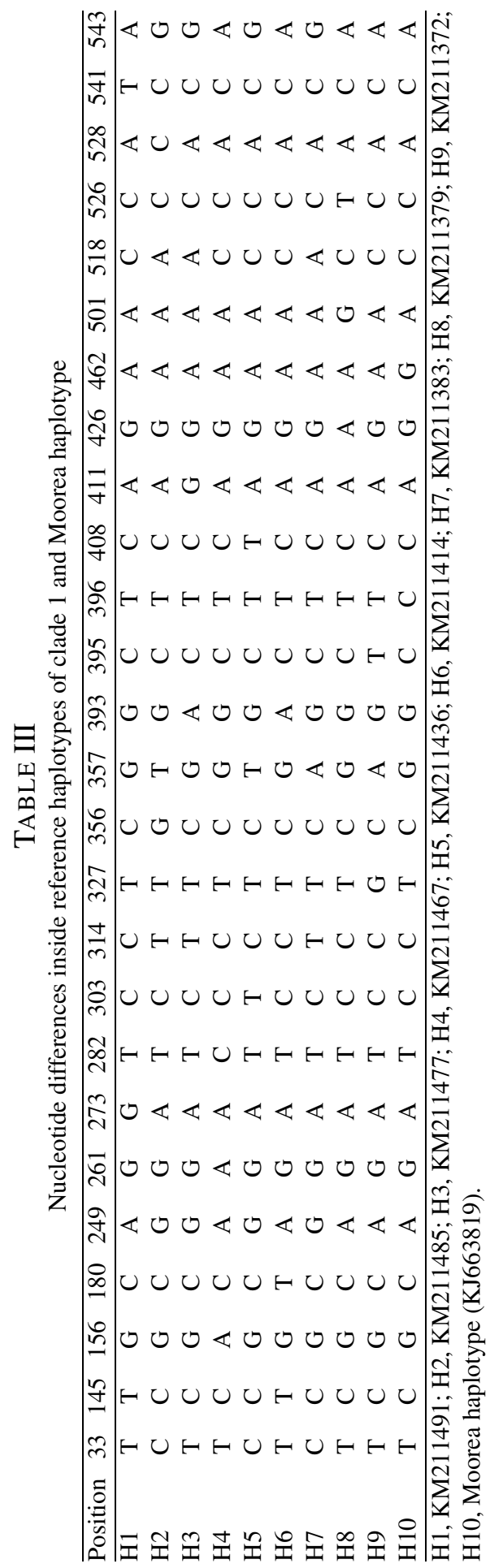


be considered a cosmopolitan species (Galil et al., 2011), and it is very difficult to trace the real origin of the invasion. According to the data, A. amphitrite seems to have been introduced just once or at least we cannot conclude the introduction by multiple hits in this area. Therefore, a deeper analysis including many other locations around the island and reference specimens from other geographical areas would be advisable.

This work shows the return to the idea that the development of the economic world leaves no area protected from alien introduction and that even small, very isolated islands, such as the Polynesian islands, are facing introduction, making the evaluation of the real impact on ecosystems difficult.

While economic development is needed, the type of tools displayed in this study can help to control and prevent the entry of invasive species and, finally, it would allow the economic development of the area together with environmental conservation of this pretty area which attracts a lot of tourism.

\section{ACKNOWLEDGEMENTS}

This study was funded by the Principado de Asturias (Spain), Reference SV-PA13-ECOEMP-41; the Ministerio de Agricultura, Alimentación y Medio Ambiente (MAGRAMA, Spain); Principado de Asturias (Spain) Grant (GRUPIN14-093). A.A. holds a regional postdoctoral Marie Curie grant (COFUND-CLARIN).

\section{REFERENCES}

Ardura, A., S. Planes \& E. Garcia-Vazquez, 2015. Aliens in Paradise. Boat density and exotic coastal mollusks in Moorea Island (French Polynesia). Mar. Environ. Res., 11: 56-63.

Carlton, J. T. \& L. G. Eldredge, 2009. Marine bioinvasions of Hawaii: the introduced and cryptogenic marine and estuarine animals of the Hawaiian Archipelago. (Bishop Museum Press, Honolulu, HI).

Carlton, J. T., W. A. Newman \& F. B. Pitombo, 2011. Barnacle invasions: introduced, cryptogenic, and range expanding Cirripedia of North and South America. In: B. S. GALIL, P. F. CLARK \& J. T. CARLTON (eds.), In the wrong place - alien marine crustaceans: distribution, biology and impacts: 159-213. (Springer, New York, NY).

Chen, H.-N., L. M. Tsang, V. C. Chong \& B. B. K. Chan, 2014. Worldwide genetic differentiation in the common fouling barnacle. Amphibalanus amphitrite. Biofouling, 30: 1067-1078.

Coles, S. L. \& L. C. EldREDGE, 2002. Nonindigenous species introductions on coral reefs: a need for information. Pac. Sci., 56: 191-209.

Endresen, Ø., H. L. Behrens, S. Brynestad, A. B. Andersen \& R. Skjong, 2004. Challenges in global ballast water management. Mar. Poll. Bull., 48: 615-623.

Excoffier, L., G. LAVAL \& S. SCHNEIDER, 2005. Arlequin (version 3.0): an integrated software package for population genetics data analysis. Evol. Bioinform. Online, 1: 47-50.

Farrapeira, C. M. R., A. V. O. M. Melo, D. F. Barbosa \& K. M. E. Silvas, 2007. Ship hull fouling in the port of Recife, Pernambuco. Brazilian J. Ocean., 55: 207-221. 
Gaither, M. R., B. W. Bowen \& R. J. Toonen, 2013. Population structure in the native range predicts the spread of introduced marine species. Proc. Roy. Soc. Lond. B: Biol. Sci., 280: 20130409.

GALIL, B. S., P. F. CLARK \& J. T. CARLTON, 2011. In the wrong place - alien marine crustaceans: distribution, biology and impacts. Invading nature. Springer Series in Invasion Ecology, Vol. 6. (Springer, Berlin).

Galil, B. S., S. Nehring \& V. E. Panov, 2007. Waterways as invasion highways: impact of climate change and globalization. Biological Invasions. Ecological Studies, 193: 59-74.

Geller, J., C. Meyer, M. PARKer \& H. HAWk, 2013. Redesign of PCR primers for mitochondrial cytochrome $\mathrm{c}$ oxidase subunit I for marine invertebrates and application in all-taxa biotic surveys. Mol. Ecol. Res., 13: 851-861.

Gollasch, S. \& M. DAVID, 2011. Sampling methodologies and approaches for ballast water management compliance monitoring. Traff. Environ., 33: 397-405.

HALL, T. A., 1999. BioEdit: a user-friendly biological sequence alignment editor and analysis program for Windows 95/98/NT. Nucleic Acids Res., 41: 95-98.

Hewitt, C. L., S. Gollasch \& D. Minchin, 2009. The vessel as a vector-biofouling, ballast water and sediments. Ecological Studies, 204: 117-129.

LePpaKoski, E., S. Gollasch \& S. OlEnin (eds.), 2002. Invasive aquatic species of Europedistribution, impact and management. (Kluwer, Dordrecht).

Mineur, F., E. J. Cook, D. Minchin, K. Bohn, A. Macleod \& C. A. Maggs, 2012. Changing coasts: marine aliens and artificial structures. Oceanogr. Mar. Biol., 50: 189-234.

Molnar, J. L., R. L. Gamboa, C. Revenga \& M. D. Spalding, 2008. Assessing the global threat of invasive species to marine biodiversity. Front. Ecol. Environ., 6: 485-492.

Occhipinti-Ambrogi, A. \& B. Galil, 2010. Marine alien species as an aspect of global change. Adv. Oceanogr. Limnol., 1: 199-218.

PALUmbi, S. R., 1996. Nucleic acids II: the polymerase chain reaction. In: Molecular systematics ( $2^{\text {nd }}$ ed.): 205-247. (Sinauer Associates, Sunderland, MA).

PosADA, D., 2008. JModelTest: phylogenetic model averaging. Mol. Biol. Evol., 25: 1253-1256.

Roberts, C. M., C. J. McClean, J. E. N. Veron \& J. P. Haw Kins, 2002. Marine biodiversity hotspots and conservation priorities for tropical reefs. Science, 295: 1280-1284.

TAMURA, K. \& M. NEI, 1993. Estimation of the number of nucleotide substitutions in the control region of mitochondrial DNA in humans and chimpanzees. Mol. Biol. Evol., 10: 512-526.

Tamura, K., G. Stecher, D. Peterson, A. Filipski \& S. Kumar, 2013. MEGA6: molecular evolutionary genetics analysis version 6.0. Mol. Biol. Evol., 30: 2725-2729.

Thompson, J. D., D. G. Higgins \& T. J. GibSON, 1994. CLUSTAL W: improving the sensitivity of progressive multiple sequence alignment through sequence weighting, position specific gap penalties and weight matrix choice. Nucleic Acids Res., 22: 4673-4680.

Tøtтrup, A. P., B. K. K. Chan, H. Koskinen \& J. T. HøEG, 2010. 'Flying barnacles': implications for the spread of non-indigenous species. Biofouling, 26: 577-582.

Wonham, M. J., W. C. Walton, G. M. Ruiz, A. M. Frese \& B. S. Galil, 2001. Going to the source: role of the invasion pathway in determining potential invaders. Mar. Ecol.-Prog. Ser., 215: $1-12$.

Yamaguchi, T., R. W. Prabowo, Y. Ohshiro, T. Shimono, D. Jones, H. Kawai, M. Otano, S. InAGAWA, T. AKAYA \& I. TAMURA, 2009. The introduction to Japan of the Titan barnacle, Megabalanus coccopoma (Darwin, 1854) (Cirripedia, Balanomorpha) and the role of shipping in its translocation. Biofouling, 25: 325-333. 
YUAN, S., J. M. AN \& Z. L. SHA, 2012. DNA taxonomy of Balanidae. Mar. Sci., 36: 82-88.

ZARDUS, J. D. \& M. G. HADFIELD, 2005. Multiple origins and incursions of the Atlantic barnacle Chthamalus proteus in the Pacific. Mol. Ecol., 14: 3719-37333. 